\title{
CROWDFUNDING DALAM PANDANGAN NEGARA KESEJAHTERAAN: DAMPAK REVOLUSI INDUSTRI 4.0 DAN COVID-19 TERHADAP PROGRAM PERLINDUNGAN SOSIAL
}

\author{
Nur Muhammaditya Priatmaja Husnanto ${ }^{1}$, Bunga Pertiwi Tontowi Puteri², \\ Rahmalia Rifandini ${ }^{3}$
}

Universitas Indonesia, Depok, Indonesia.

atyanuradji@gmail.com

$\underline{\text { Received : } 10 \text { June } 202 \text { | Reviewed: } 27 \text { June } 2021 \text { | Accepted: } 15 \text { July } 2021}$

\begin{abstract}
ABSTRAK
Kajian ini bertujuan menawarkan solusi pandangan negara kesejahteraan terhadap crowdfunding sebagai sebuah platform big data PMKS mengoptimalkan program perlindungan sosial. Revolusi Industri 4.0 dan pandemi Covid-19 secara sistemik, membawa perubahan program perlindungan sosial dalam bentuk big data terintegrasi dari pemerintah pusat sampai daerah dan mempercepat arus perubahan. Sementara beban Kemensos dalam program perlindungan sosial begantung pada struktur APBN yang mempunyai keterbatasan anggaran. Program Keluarga Harapan (PKH) sebagai alat intervensi pemerintah menjembatani program perlindungan sosial yang terkoneksi dengan data kesehatan, pendidikan, dan layanan sosial perlu beradaptasi dengan perubahan. Dengan menggunakan soft system dynamic methodology (SSDM), pendekatan negara kesejahteraan melalui konsep crowdfunding, dapat memperluas cakupan penerima layanan perlindungan sosial serta mempertajam ketepatan sasaran penerima yang dikelola terintegrasi dengan big data. Peneliti melakukan analisis customers, actors, transformation process, worldview, owners, dan environmental constraints CATWOE dan menggunakan aplikasi Vensim. Hasil pengolahan data berupa diagram kausalitas (CLD) sistem berpikir menggambarkan kondisi sebenarnya terhadap perbandingan kausalitas sistem berpikir seharusnya.
\end{abstract}

Kata Kunci: Perubahan Sosial Ekonomi, Pembangunan, Jalur Lintas Selatan

Korespondensi:

Universitas Indonesia, Depok, Indonesia.

Jl. Margonda Raya, Pondok Cina, Kecamatan Beji,

Kota Depok, Jawa Barat 16424

E-mail: atyanuradji@gmail.com 


\begin{abstract}
This study aims to offer solution for the welfare state's view of crowdfunding as a big data platform for PMKS optimized social protection programs. The Industrial Revolution 4.0 brings changes in social protection programs in the form of integrated big data from central to local governments. Systemically, the Covid-19 pandemic is accelerating the flow of change. Meanwhile, the solution of the Ministry of Social Affairs is highly dependent on the structure of the APBN which is relatively less adaptive with rapid changes due to disasters. The Family of Hope Program (PKH) as a means of government intervention bridging social protection programs that are connected to data on health, education and social services needs to adapt to change. By using soft system dynamic methodology (SSDM), welfare state approach through the concept of crowdfunding, can expand the coverage of social protection service recipients and sharpen the accuracy of targeting recipients who are managed integrated with big data. The researcher analyzes customers, actors, transformation processes, world views, owners, and environmental constraints of CATWOE and uses Vensim software. The results of data processing in the form a causality diagram (CLD) of the thinking system describe actual conditions against causality comparison of the thinking system
\end{abstract}

Keyword : Welfare State, Social Protection, Industrial Revolution 4.0, Soft-system Dynamic Methodology, Covid -19.

\title{
PENDAHULUAN
}

Dampak revolusi industri 4.0 (RI 4.0) terhadap perlindungan sosial menghadirkan tata kelola Program Keluarga Harapan (PKH) yang adaptif terhadap big data dan internet (Manalu, 2019). Kehadiran e-PKH mempermudah proses validasi tanpa kertas dan berkas, membantu menghitung bantuan sosial secara otomatis, serta memasukkan hasil verifikasi komitmen Keluarga Penerima Manfaat (KPM) secara cepat. Perubahan adaptif program perlindungan sosial terhadap teknologi berdampak pada ketepatan dan monitoring capaian kinerja program. Hasil uji efektivitas PKH mampu mengentaskan kemiskinan di daerah perbatasan melalui indikator penurunan angka putus sekolah, peningkatan kunjungan fasilitas kesehatan, serta kemampuan memenuhi kebutuhan pokok yang bersumber dari penyisihan dana bantuan (Beni dan Manggu, 2020).

Dampak positif PKH dalam menanggulangi kemiskinan tidak terlepas dari fungsi perlindungan sosial dalam bentuk Conditional Cash Transfers (CCT) (Michelle Adato and John Hoddinott, 2007; Lauri Heimo, 2014). CCT merupakan sebuah program yang memberikan sejumlah uang kepada masyarakat miskin sebagai imbalan karena telah memenuhi kondisi atau perilaku tertentu. CCT menggabungkan perlindungan sosial berbasis hak, 
perlindungan sosial hemat biaya, dan perlindungan sosial produktif berdasarkan pandangan ekonomi investasi sosial. Di Indonesia, CCT yang berbentuk PKH mensinergikan data keluarga miskin ke dalam layanan kesehatan, layanan pendidikan, dan perlindungan sosial lainnya (Kemensos, 2020). Dalam posisi ini, pengelolaan data keluarga miskin ke dalam big data menjadi sangat esensial mengatasi kemiskinan karena berkaitan dengan ketepatan dan kecepatan serta capaian program.

Studi tentang PKH sudah banyak dilakukan, misalnya, penerima PKH yang diidentifikasi tidak layak menerima (non eligible) karena konstruksi sosial pendidikan (Munari Kustanto, 2019). Penelitian lain yaitu tentang dampak positif program PKH terhadap keluarga miskin menjadi hidup mandiri melalui sadar pendidikan dan kesehatan. Namun, temuan lain menyatakan masih banyaknya mental miskin yang secara indikator tidak masuk kategori keluarga miskin tetapi mengkonstruksi dirinya miskin (Eky Risqiana, 2019).

Peningkatan kesejahteraan dan pengurangan kemiskinan selama enam tahun PKH berjalan, mengalami tren yang positif. Akan tetapi, aspek pemberdayaan PKH yang mengubah keluarga miskin menjadi keluarga produktif sebagai upaya untuk keluar dari perangkap kemiskinan, dinilai tidak cukup. Hasil penelitian Kementerian Sosial dan Australian Government (MAHKOTA dan SMERU, 2020) menunjukkan perlu adanya langkah lanjutan yang mensinergikan program perlindungan sosial dan pemberdayaan. Rekomendasi penelitian menyebutkan bahwa PKH kedepan harus mampu menjadi peluang ekonomi. Terutama dalam bentuk keterlibatan usaha mikro yang berkelanjutan, seperti memfasilitasi petani menghasilkan barang sesuai permintaan pasar, menumbuhkan hubungan pasar yang lebih kuat antara PKH dan pembeli lokal, dan mentransformasikan KUBE (Kelompok Usaha Bersama) PKH menjadi program inklusi produktif. Rekomendasi lain yaitu PKH harus mampu melakukan transformasi keluarga miskin menjadi keluarga produktif dengan melibatkan anggota PKH dalam pekerjaan sektor formal.

Untuk mewujudkan transformasi keluarga miskin menjadi keluarga produktif melalui pemberdayaan, dibutuhkan keterlibatan banyak pihak serta dukungan anggaran yang proporsional. Tidak hanya menggantungkan pada paket APBN. Alih-alih merencanakan PKH berkelanjutan dengan anggaran yang cukup, Indonesia justru sedang mengalami pelambatan perekonomian karena pandemi Covid-19 yang menyerang sejak Februari 2020. Pertumbuhan ekonomi defisit hingga 3,8\% di kuartal II 2020 (Kompas, 2020). Melemahnya perekonomian berdampak pada postur APBN tahun 2021 karena realisasi penerimaan pajak yang tidak sesuai 
sasaran (Kompas, 2020). Dampak pandemi juga berpengaruh terhadap meningkatnya keluarga miskin baru dari 9,22\% atau 24,79 juta jiwa per September 2019, bertambah sebanyak 6,88 juta orang atau setara 4,99\% pada Februari 2020 (Detik Finance, 2020). Dengan kondisi APBN yang tertekan, maka sangat kecil kemungkinan negara mampu memberikan perlindungan sosial melebihi paket PKH yang sudah direncanakan.

Perlu rancangan kebijakan perlindungan sosial baru yang adaptif terhadap kebutuhan masyarakat di tengah pandemi dalam mentransformasikan masyarakat miskin menjadi masyarakat produktif. Pemberdayaan sebagai kewajiban pemerintah melindungi segenap warga. Berdasarkan latar belakang tersebut, penelitian ini ingin menjawab bagaimana potensi crowdfunding sebagai solusi keberlanjutan perlindungan sosial di Indonesia.

Berdasarkan literatur sebelumnya konsep negara kesejahteraan adalah upaya yang dilakukan negara sebagai bukti pemerintahan yang sah (legitimated) untuk melindungi segenap warga (Paul Spicker, 2000). Pandangan ini dapat dikombinasikan ke dalam konsep crowdfunding yang dapat diinisiasi oleh pemerintah ke dalam pelayanan e-PKH yang adaptif. Melalui big data yang mengintegrasikan perlindungan sosial dan pemberdayaan masyarakat. Sementara gagasan mengenai crowdfunding banyak diulas dalam ekonomi dan dikembangkan terutama dalam industri seni dan kreativitas. Secara umum crowdfunding adalah usaha pengumpulan dana dari masyarakat banyak (crowd) untuk membiayai suatu program. Perkembangan crowdfunding memiliki beberapa karakteristik yang berbeda dari bentuk pengumpulan dana lainnya, yaitu: 1) jumlah partisipasi menjadi hal yang penting dibanding dengan jumlah donasi (Irfan, 2016); 2) menggunakan teknologi dan media digital sebagai medium, sehingga membangun hubungan yang bersifat interaktif (Gea, 2016); 3) terdapat tiga pelaku utama yaitu inisiator yang memiliki program atau ide untuk didanai, kerumunan masyarakat yang menjadi penyandang dana, dan platform yang menjadi organisator crowdfunding (Agriwal, 2014).

Faktor intrinsik seperti kepuasaan pribadi dan penghargaan bersifat emosional menjadi motivasi yang kuat untuk donatur berpartisipasi (Cecere dkk, 2017). Sisi ekonomi menunjukkan bahwa kegiatan crowdfunding didasari oleh sikap mental kebersamaan untuk mewujudkan suatu hubungan timbal-balik yang tidak hanya dilandasi oleh kepentingan finansial Irfan (2016) dan Gea (2016). Meskipun model investasi pendanaan crowdfunding terus dikembangkan, akan tetapi perlu penekanan sikap mental kebersamaan menjadi sentral dalam bentuk-bentuk crowdfunding. Kerjasama dan kolaborasi merupakan narasi yang ditawarkan oleh organisasi crowdfunding kepada masyarakat. Bersama menjalankan inovasi 
dan inisiatif sosial untuk program sosial kemasyarakatan, seperti yang dilakukan oleh platform Kitabisa.com, atau yang berbasis investasi seperti gandengtangan.org dan TaniHub.

Berawal dari transformasi perlindungan sosial era industri 4.0 ditengah situasi pandemi, penelitian ini mengajukan argumen karakteristik crowdfunding berupa pendanaan dari masyarakat dapat diimplementasikan ke dalam program perlindungan sosial. Dengan demikian, penelitian ini menekankan pentingnya pengolahan data terpadu yang belum banyak dibahas dalam kajian sebelumnya. Benefit bagi pemerintah adalah tersedianya alternatif pembiayaan perlindungan sosial, sedangkan dari sisi masyarakat berupa keterlibatan dalam bentuk solidaritas sosial yang memperkuat modal sosial dan merajut simpul persatuan. Dampak kewajiban negara melaporkan penggunaan dana masyarakat membuat informasi perlindungan sosial semakin transparan dan akuntabel. Praktik pandangan negara kesejahteraan dalam perlindungan sosial melalui bentuk crowdfunding terhadap perubahan RI 4.0 dan dampak Covid-19 akan dijelaskan lebih lanjut menggunakan analisis Soft System Dynamic Methodology (SSDM) dengan sumber data digital paper

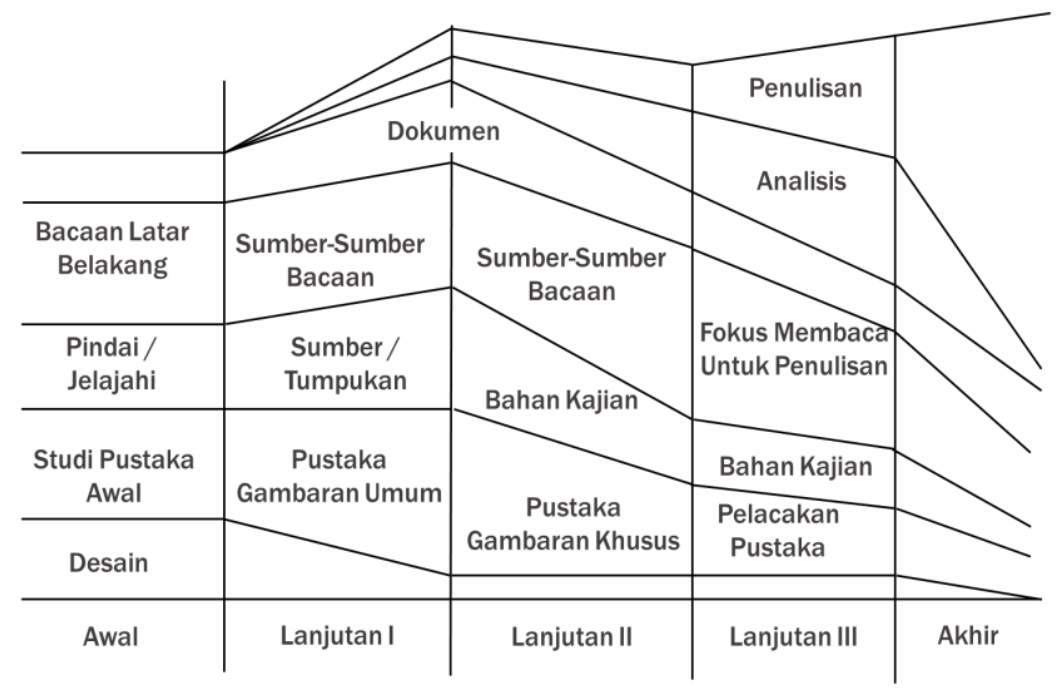

Gambar 1

Tahapan Metodologi Proses Penulisan

Sumber: Disarikan dari Andrew Abbott, 2014, 5. Keterangan: tahapan pengumpulan data yang dilakukan bersifat unlinear sesuai dengan kebutuhan di setiap tahapan.

Penelitian ini mendasarkan pada teori multi metodologi yang mengkombinasikan paradigma system thinking yaitu Soft-system Methodology (SSM) dan System Dynamics (SD) 
(Ricardo Rodriguez-Ulloa dan Alberto Paucar-Cacerez, 2005). SSM merupakan sebuah metodologi yang digunakan untuk mengamati sebuah sistem sosial dengan mengidentifikasi berbagai kondisi dan sudut pandang untuk masing-masing dipetakan, sehingga dinamika situasi dari sistem sosial tergambarkan (Williams \& Hummelbrunner, 2009).

$S D$ merupakan pendekatan untuk memahami perilaku dinamis sistem sosial dengan mengamati lingkaran-lingkaran (loop) umpan balik yang tidak linier, dengan dasar pemikiran bahwa nilai dari suatu elemen dapat berubah-rubah melalui mekanisme arus keluar dan arus masuk (Williams \& Hummelbrunner, 2009).

Kerangka kerja SSDM (Soft System Dynamics Methodology, gabungan SSM dan SD) secara teoritik dilakukan dalam 10 (sepuluh) langkah kerja, yaitu Tahap 1 situasi permasalahan yang tidak terstruktur; Tahap 2 struktur kondisi atau situasi; Tahap 3 permasalahan berorientasi pada Root Definitions, yaitu usaha untuk menggali akar dari mana segala sesuatu itu tumbuh dengan melihat hasil dari sebuah hubungan ; Tahap 4 membangun model dinamika sistem berbasis situasi problematika; Tahap 5 membandingkan tahap 4 atau tahap 7 dengan tahap 2; Tahap 6 menentukan perubahan yang layak secara budaya dan diinginkan secara sistem; Tahap 7 membangun model sistem dinamis dari 'solving situation'; Tahap 8 solving situationoriented root definitions; Tahap 9 implementasi perubahan yang layak dan diinginkan di dunia nyata; Tahap 10 poin pembelajaran.

Pengumpulan data menggunakan studi pustaka digital paper dari berbagai sumber seperti e-jurnal, website, e-book, dan digital media dimulai pada bulan Mei 2020 sampai dengan Juli 2020. Secara sistemik kegiatan yang dilakukan oleh peneliti simultan dan paralel tidak bersifat linier tetapi dapat dilakukan secara bersama yang terbagi menjadi awal,lanjutan, dan akhir (Andrew Abbott, 2014).

Validasi terhadap dokumen yang diperoleh menggunakan url sumber resmi pemerintahan, hasil jurnal bereputasi dan terindeks global, serta mengkomparasi pandangan yang sama dari sudut yang berbeda dari bahan lainnya sebagai bagian dari triangulasi data (Barbara M. Wildemuth, 2017).

Pengumpulan data digital paper awal akan dianalisis menggunakan SSDM untuk menggambarkan tiga tahapan awal SSDM yaitu 1. Situasi permasalahan yang tidak terstruktur; 2. Struktur kondisi atau situasi real world yang digambarkan dengan Rich Picture; 3. Permasalahan - (oriented root definition) yang dibantu dengan analisis Customers, Actors, Transformation, World View, Owner, Environmental (CATWOE). 
Perbandingan kondisi antara real world pada langkah 4 berupa dynamic problematic situation model dengan theoretical world langkah 7 berupa dynamic solving situation model dikategorikan sebagai langkah 5 untuk mencari perbedaan dan persamaan. Langkah 6 adalah intervensi budaya dari sisi kelayakan dan keinginan untuk berubah. Kemudian langkah 8 yaitu root definition baru menggunakan CATWOE perubahan sebagai upaya pemecahan masalah. Selanjutnya, langkah 9 berupa penerapan di dunia nyata beberapa poin hasil temuan langkah 8. Terakhir, Langkah 10 yaitu mengambil hasil pembelajaran dari proses SSDM.

\section{PEMBAHASAN}

\section{Situasi Permasalahan Tidak Terstruktur}

Gambaran kondisi permasalahan konteks real world dalam berpikir sistem dapat dijabarkan melalui jalinan setiap simpul yang berkaitan. Dimulai dari dampak revolusi industri 4.0 dan Covid-19 terhadap program perlindungan sosial PKH yang dilihat dari berbagai sumber data. Kemensos menyatakan revolusi industri mempengaruhi pengelolaan big data dan penggunaan internet of things untuk mempercepat proses dan meningkatkan validasi (Manalu, 2019).

Keberhasilan cakupan e-PKH mempermudah proses penyaluran bantuan dalam pencapaian target 10 juta peserta di tahun 2019 (Ristu Hanafi, 2019). Berdasarkan laporan penguatan peluang ekonomi keluarga penerima PKH di empat kabupaten di Jawa, kemampuan program dalam meningkatkan perekonomian keluarga hanya 12\% pada tahun 2019 dari keluarga penerima manfaat tahun 2017 dan 2018. Menurut Kemensos, lemahnya kemampuan peningkatan ekonomi karena rendahnya kolaborasi antara PKH dengan Kredit Usaha Rakyat (KUR) atau program Pembiayaan Ultra Mikro (UMi) (MAHKOTA \& SMERU, 2020).

Selanjutnya, tulisan ini memetakan persoalan PKH yang terkait dengan penerima program. Wabah Covid-19 telah berdampak terhadap penambahan kelompok miskin sebesar 4,99\% atau sebanyak 6,88 juta orang yang belum terjaring dalam PKH. Angka ini diproyeksikan menjadi tambahan KPM dalam beberapa tahun ke depan. Penambahan jumlah KPM diprediksi seiring dengan pertumbuhan ekonomi yang melambat.

Beberapa kajian menunjukkan bahwa KPM memiliki ketergantungan yang tinggi terhadap program $\mathrm{PKH}$, sehingga mereka cenderung untuk tidak mau melakukan graduasi 
mandiri (Habibullah, 2017; Ayurestianti, 2017; Suleman dan Resnawaty, 2019; Risqina 2020; Beni dan Manggu 2020; Sari dan Marom 2020). Salah satunya karena tidak adanya program pemberdayaan lanjutan yang mendorong mereka untuk mengembangkan ekonomi produktif. Selain itu, karena program yang ada tidak melibatkan partisipasi masyarakat, sehingga masyarakat hanya tahu menerima bantuan. Program lanjutan dari PKH dinilai penting untuk mewujudkan perlindungan sosial yang lebih komprehensif.

Masalah lain terdapat terkait perbandingan kualitas pendidikan dan kesehatan yang didapatkan KPM di kawasan perbatasan Indonesia lebih rendah, dibandingkan dengan kualitas pendidikan dan kesehatan yang ada di negara tetangga (Beni dan Manggu 2020). Peningkatan kualitas pada bidang pendidikan dan kesehatan dipandang perlu untuk diupayakan, agar kualitas hidup KPM meningkat.

Pada bidang kesehatan peningkatan kualitas tidak hanya pada fasilitas dan pelayanan namun juga program nutrisi seimbang yang selama ini belum dijalankan dengan baik, karena masih berfokus pada pemenuhan beras sebagai makanan pokok (Habibullah, 2017). Sedangkan, bidang pendidikan perlu memperhatikan masalah akses (Beni dan Manggu 2020), karena tidak sedikit kendala bersekolah adalah masalah biaya dan keamanan akses menuju ke sekolah. Meskipun di satu sisi masih terdapat kesadaran yang rendah dari masyarakat untuk memprioritaskan sekolah (Sari dan Marom, 2020).

Pemetaan berikutnya mengenai hambatan fasilitator dalam memberikan pendampingan sosial kepada KPM. Studi-studi Ariwibowo dan Lina F (2019), Susantyo, Badrun dan Togiaratua (2018), Ocktilia dan Desi (2018), Riswantoro (2018) mengemukakan persoalan yang dihadapi fasilitator. Fasilitator mengalami beban kerja di lapangan dengan sistem penggajian yang tidak seimbang. Kemudian, mendapat benturan respon dari komunitas adat karena perbedaan nilai yang diyakini terhadap program kegiatan P2K2 (Pertemuan Peningkatan Kemampuan Keluarga). Namun disisi lain, ada yang mengatakan bahwa fasilitator belum optimal melakukan pendampingan karena kurang memahami kepentingan dari kegiatan P2K2. Persoalan akurasi data juga masih menjadi kendala dalam memastikan target intervensi program, sehingga menghambat integrasi perlindungan sosial. 
Transformasi perlindungan sosial menuju masyarakat produktif juga sejalan dengan pandangan TNP2K (Tim Nasional Percepatan Penanggulangan Kemiskinan) selaku organisasi yang dibentuk pemerintah untuk mengharmonisasi kebijakan perlindungan sosial di masingmasing Kementerian/Lembaga. Bersama dengan organisasi di luar pemerintahan, disimpulkan bahwa masa depan perlindungan Indonesia tidak hanya hadir bagi kelompok miskin tetapi juga mereka yang rentan di kelas menengah atau missing middle seperti kelompok pekerja sektor informal, anak-anak dan kelompok lanjut usia.

Dengan mengusung konsep perlindungan sosial sepanjang hayat, maka area yang dicita-citakan akan mampu melindungi anak usia pra sekolah, usia sekolah, usia produktif, dan lansia (TNP2K, 2018). Dalam laporan Bappenas tantangan perlindungan sosial ke depan adalah optimalisasi sumber pendanaan yang sampai saat ini masih bergantung pada pendanaan pemerintah berupa APBN dan APBD (Bappenas, 2014). Beberapa sumber alternatif yang turut diusulkan berupa praktik zakat, infaq, dan shadaqah, serta melibatkan pihak swasta dalam bentuk corporate social responsibility (CSR).

Saat ini dalam aspek sumber pendanaan, program perlindungan sosial diatur oleh peraturan menteri keuangan nomor 102/PMK02/2018 yang diklasifikasikan ke dalam anggaran perlindungan sosial. Mekanisme pengusulan dilakukan dengan merencanakan target sesuai Rencana Pembangunan Jangka Menengah Nasional (RPJMN) yang dilakukan satu tahun sebelumnya dalam bentuk rencana kerja dan anggaran kementerian. Besaran anggaran mengacu pada capaian anggaran di tahun sebelumnya. Dengan menggunakan mekanisme plan follow the budget, maka mekanisme perlindungan sosial bersifat target tahunan yang akan meredusir kemiskinan tetapi tidak dapat menghilangkannya.

Kondisi yang terjadi adalah, seandainya program PKH dihentikan di tahun 2020 dan masyarakat miskin tidak juga berpindah menjadi masyarakat produktif, prestasi pengurangan kemiskinan melalui PKH rendah karena hanya $12 \%$ yang mampu melakukan perubahan menjadi masyarakat produktif. Perlu dilakukan alternatif pembiayaan yang tidak bersumber dari APBN dan dapat terintegrasi langsung ke dalam data perlindungan sosial sekaligus pemberdayaan masyarakat untuk menjamin keberlangsungan kesejahteraan. 
Sementara itu, anggaran APBN dan stimulus pemerintah terhadap perbaikan ekonomi karena pandemi Covid-19 salah satunya bersumber pada hutang luar negeri. Kebijakan yang dilaksanakan dapat berupa keringanan pajak dan insentif bagi dunia usaha. Kebijakan lain berupa perlindungan sosial bagi kelompok miskin dalam bentuk asistensi sosial temporer BLT (Bantuan Lansung Tunai) dan paket sembako. Kedua bentuk kebijakan akan berdampak pada beban utang negara (Lidya Julita S \& Cantika Adinda Putri, 2020).

Pengumpulan dana masyarakat yang bertujuan meningkatkan kesejahteraan rakyat dan dikelola oleh Kemensos bukan sesuatu yang baru. Dalam kurun waktu sepuluh tahun terakhir, terdapat Permensos 176 tahun 2011 yang kemudian dicabut diganti oleh Permensos 14 tahun 2012 dan kemudian dicabut kembali digantikan Permensos nomor 8 tahun 2019. Pada Permensos terakhir berisi tentang pengelolaan hasil pengumpulan sumbangan masyarakat dari penyelenggaraan undian gratis berhadiah dalam bentuk uang. Sesuai dengan tujuannya, Permensos membatasi diri pada penerimaan yang diperoleh dari sumbangan Undian Gratis Berhadiah (UGB) karena hadiah tidak tertebak atau hadiah tidak diambil pemenang. Sumber lain dapat berupa dana kesejahteraan sosial yang disisihkan oleh penyelenggara UGB berupa dana hibah dalam negeri berupa uang.

\section{Struktur Real World Menggunakan Rich Picture}

Rich Picture merupakan sebuah terminologi yang menunjukkan gambar sebuah situasi yang menggungkapkan segala "kekayaan” elemen-elemen (struktur, proses, orang, isu, konflik dan suasana) (Williams \& Hummelbrunner, 2009). Pada Rich Picture (RP) dapat dilihat hubungan perlindungan sosial secara sistemik dengan berbagai aktor dan bagaimana melihat perlindungan sosial untuk meningkatkan kelompok miskin menjadi sejahtera. Secara garis besar dalam hal pendanaan, terdapat ketergantungan keberlangungan program melalui anggaran pemerintahan. Dalam aspek organisasi di luar pemerintahan terdapat masukan bahwa perlindungan dalam pengentasan kemiskinan tidak cukup tetapi harus di dorong ke ranah pemberdayaan masyarakat sepanjang hayat. Sedangkan dalam hal pelayanan PKH terhadap 
KPM masih memiliki catatan seperti kualitas pendidikan, kendala teknis dan ketergantungan pada program.

\section{Gambar 2}

Rich Picture Berdasarkan Situasi Permasalahan

Sumber (Hasil analisis Penulis Unstructure Problem Situation Fase 1)

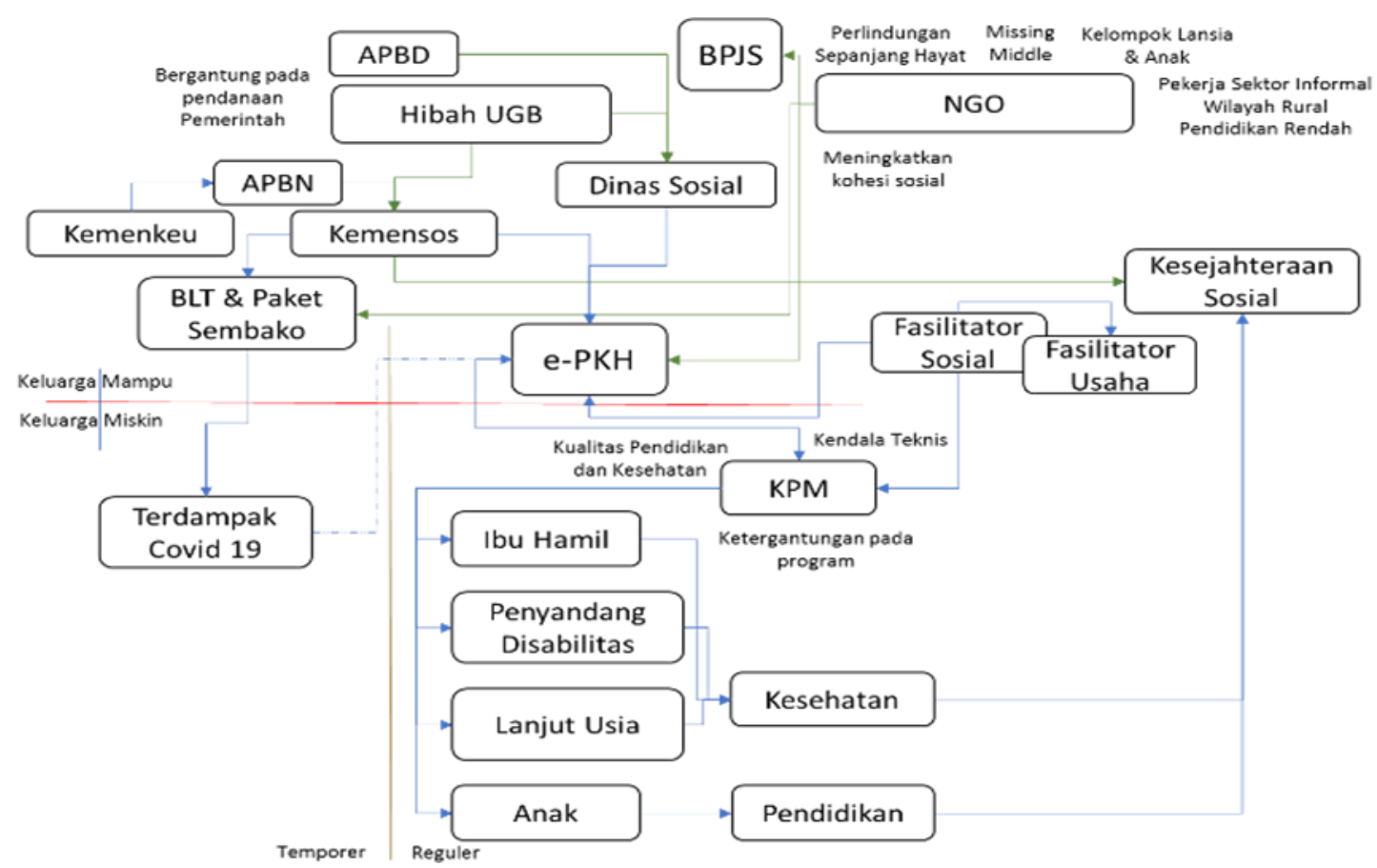

Permasalahan

Tabel 1

Root Definition Berdasarkan Situasi Permasalahan 

Rifandini

\begin{tabular}{|l|l|l|}
\hline \multicolumn{1}{|l|}{ ROOT DEFINITIONS } & \multicolumn{1}{c|}{ Melalui Y } & \multicolumn{1}{c|}{ Menghasilkan Z } \\
\hline \multicolumn{1}{|c|}{ Tindakan X } & \multicolumn{1}{c|}{ Pemberdayaan KPM } & Kesejahteraan Sosial \\
\hline Perlindungan sosial & Optimalisasi Pembiayaan Alternatif & Perlindungan sosial komprehensif \\
\hline Pembiayaan & & \\
\hline ExBN/APBD & Memberikan perlindungan Missing Middle & Perlindungan sepanjang hayat \\
\hline
\end{tabular}

Sumber (Hasil analisis Penulis Unstructured Problem Situation Fase 1)

Tabel 2

Analisis CATWOE berdasarkan situasi permasalahan.

\begin{tabular}{|c|c|}
\hline $\begin{array}{l}\text { Elemen } \\
\text { CATWOE }\end{array}$ & Perlindungan Sosial \\
\hline Customers & $\begin{array}{l}\text { Kelompok Penerima Manfaat (KPM) dan Masyarakat Miskin yang terdiri dari Anak, Usia } \\
\text { Produktif, Lanjut Usia, dan Ibu Hamil }\end{array}$ \\
\hline Actors & Kemensos, Dinas Sosial, Organisasi di luar pemerintahan, Fasilitator \\
\hline $\begin{array}{l}\text { Trans- } \\
\text { formation }\end{array}$ & $\begin{array}{l}\text { Perubahan yang ingin dicapai adalah menurunkan angka kemiskinan dengan memberikan } \\
\text { perlindungan pada kelompok miskin untuk bisa bertahan hidup. Transformasi lain yang } \\
\text { ingin dicapai menjadi masyarakat produktif yang tidak lagi bergantung pada program } \\
\text { perlindungan sosial. }\end{array}$ \\
\hline \multirow[t]{3}{*}{ World-view } & $\begin{array}{l}\text { Kemensos dan dinas sosial berpandangan CCT dalam bentuk PKH di Indonesia secara } \\
\text { efektif sukses menurunkan angka kemiskinan. Upaya yang akan dilakukan kedepan untuk } \\
\text { mencapai transformasi dengan memperluas jangkauan bantuan dan ketepatan sasaran bagi } \\
\text { mereka yang sesuai dengan kriteria penerima perlindungan. }\end{array}$ \\
\hline & $\begin{array}{l}\text { Organisasi di luar pemerintahan berpandangan konsep perlindungan sosial dalam bentuk } \\
\text { PKH perlu di tingkatkan dalam bentuk perlindungan sepanjang hayat diawali dari usia pra } \\
\text { sekolah, sekolah, produktif dan lansia. Rentannya kelompok missing middle yang mudah } \\
\text { mengalami gejolak stabilitas ekonomi ketika terjadi peristiwa tertentu seperti dampak } \\
\text { Covid } 19 \text {, maka perlu dimasukkan kedalam program perlindungan sosial tidak hanya } \\
\text { berfokus pada masyarakat miskin. }\end{array}$ \\
\hline & $\begin{array}{l}\text { Fasilitator berpandangan keberhasilan } \mathrm{PKH} \text { didukung oleh sosialisasi dan pendampingan } \\
\text { kepada masyarakat miskin salah satunya melalui pertemuan peningkatan kapasitas } \\
\text { keluarga (P2K2) }\end{array}$ \\
\hline Owners & Kemensos, Dinas Sosial, Organisasi di luar pemerintahan \\
\hline $\begin{array}{l}\text { Environ- } \\
\text { mental Cons- } \\
\text { traints }\end{array}$ & $\begin{array}{l}\text { Kebijakan PKH diciptakan dalam lingkungan demokrasi pancasila yang berupaya } \\
\text { menciptakan keadilan sosial bagi seluruh rakyat indonesia. Sehingga sasaran program } \\
\text { berfokus pada kelompok miskin yang sangat rentan mengakses fasilitas kesehatan, } \\
\text { pendidikan, dan nutrisi yang menunjang. Terdapat beberapa kendala yang akan dihadapi } \\
\text { yaitu kuota pendanaan APBN yang terbatas untuk perlindungan sosial, adanya tekanan } \\
\text { penggunaan teknologi digital, dan kondisi pandemi yang mendorong new normal }\end{array}$ \\
\hline
\end{tabular}

Sumber (Hasil Analisis Penulis Unstructure Problem Situation Fase 1)

\section{Model Dinamika Permasalahan menggunakan Causal Lood Diagram (CLD)}

Berdasarkan analisa CATWOE dan RP di dapat permodelan menggunakan SD berupa Causal Loop Diagram yang menghubungkan berbagai variabel. Metode CLD ini digunakan untuk memahami pola relasi dan situasi dinamis, dengan menghubungkan variabel-variabel 
dan menunjukkan hubungan sebag-akibat diantara variabel, dimana konsep dasarnya adalah "feedback" yang digambarkan menggunakan loop (lingkaran) (Williams \& Hummelbrunner, 2009). Model SD sesuai pada tahap 3 menghubungkan setiap root definition dengan menekankan bahwa konteks diagram dibuat sebagai dasar cara model konseptual kerja yang digunakan dalam SSM, dengan menggambarkan dunia nyata dan dalam istilah sistemik, hermeneutik, fenomenologis dan epistemologis. Sehingga penggunaan kata kerja diperlukan untuk memenuhi syarat dalam diagram, bukan "nouns" dan substantif yang digunakan dalam SD. Hubungan itu ada tiga macam yaitu hubungan sebab akibat, perubahan materi dan perubahan informasi. Diagram konteks ini dapat dilihat pada bagan 4 yang berbasis pada masalah pada tahap sebelumnya. Sedangkan bagan 5 adalah diagram sebab akibat problematik dari interpretasi khusus dari situasi-masalah berdasarkan definisi akar bermasalah yang disajikan pada tahap 3 .

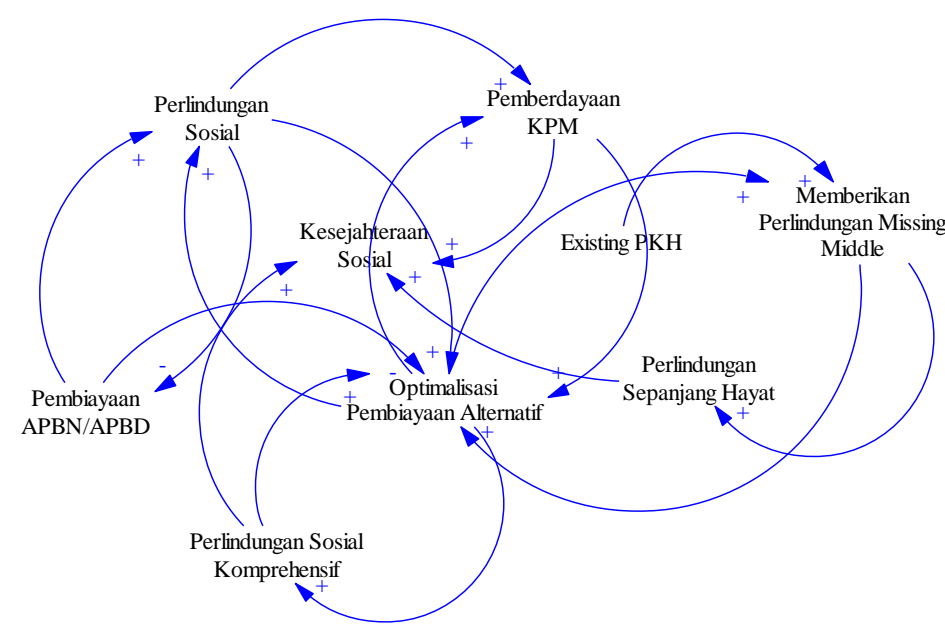

Gambar 3

Causal Loop Diagram Situasi Permasalahan

Sumber (Analisis Penulis Root Definition dan CATWOE tahap 3)

Tabel 3

Karakteristik looping

Loop Number 1 of length 1

Optimalisasi Pembiayaan Alternatif -Perlindungan

Sosial Komprehensif (Reinforcing)

Loop Number 2 of length 1
Loop Number 4 of length 1

Optimalisasi Pembiayaan Alternatif-Perlindungan Sosial (Reinforcing)

Loop Number 5 of length 2 


\begin{tabular}{|l|l|}
\hline $\begin{array}{l}\text { Optimalisasi Pembiayaan Alternatif-Pemberdayaan } \\
\text { KPM (Reinforcing) }\end{array}$ & $\begin{array}{l}\text { Optimalisasi Pembiayaan Alternatif- } \\
\text { Perlindungan Sosial (Reinforcing)-Pembiayaan } \\
\text { APBN/APBD (Balance to Reinforcing) }\end{array}$ \\
$\begin{array}{l}\text { Optimalisasi Pembiayaan Alternatif-Memberikan } \\
\text { Perlindungan Missing Middle (Reinforcing) }\end{array}$ & $\begin{array}{l}\text { Optimalisasi Pembiayaan Alternatif- } \\
\text { Perlindungan Sosial (Reinforcing)- } \\
\text { Pemberdayaan KPM (Reinforcing) }\end{array}$ \\
\hline
\end{tabular}

Sumber (Hasil Analisis Penulis Root Definition dan CATWOE tahap 3)

Menggunakan sudut pandang ini maka, variabel optimalisasi pembiyaan alternatif menjadi penyebab tidak langsung dari peningkatan kesejahteraan sosial. Sedangkan semua variable penyebab kesejahteraan sosial, dipengaruhi oleh variable optimalisasi pembiayaan alternative. Sehingga variabel optimalisasi pembiayaan alternatif merupakan variabel yang memiliki paling banyak loop dalam usaha peningkatan kesejahteraan, dengan keseluruhan sifat loop berupa Reinforcing. Reinforcing adalah situasi dimana semua variabel merespon satu sama lain dalam arah yang sama, sehingga antar variabel memiliki hubungan yang saling menguatkan (Williams \& Hummelbrunner, 2009). Kesimpulan CLD dimungkinkan variabel optimalisasi pembiayaan alternatif merupakan variable kunci, atau variabel leverage yang jika dilakukan perbaikan berfokus pada optimalisasi pembiayaan alternatif akan berdampak pada variabel lainnya dalam mentransformasikan masyarakat miskin menjadi masyarakat produktif.

\section{Membandingkan model CLD Tahap 4 atau model penyelesaian permasalahan tahap 7 terhadap Tahap 2 Rich Picture.}

Pada RP dapat dilihat bahwa aspek pendanaan memiliki permasalahan berupa keterbatasan dan ketergantungan terhadap pembiayaan pemerintah. Sedangkan pada aspek penerimaa manfaat (KPM) memiliki permasalahan berupa kendala teknis, ketergantungan terhadap program perlindungan, serta rendahnya kualitas pendidikan dan kesehatan. Pada aspek fasilitator program, terdapat ketidak berimbangan beban kerja di lapangan dengan sistem penggajian. Pada aspek dorongan organisasi di luar pemerintah serta kajian TNP2K program CCT tidak cukup menyelesaikan kemiskinan. Perlu dimensi pemberdayaan untuk memastikan KPM betul-betul mampu menjadi keluarga mandiri tanpa ketergantungan pada program. Sementara, kelompok organisasi juga mendorong perlindungan sosial yang lebih inklusif menyasar pada kelompok kelas menengah yang rentan missing middle terutama di sektor 
informal yang sampai saat ini tidak ada perlindungan sosial pemerintah yang melayani kebutuhan mereka.

Perbandingan tahap 2 berupa RP dengan model tahap 4 memberikan titik tumpu pada optimalisasi pembiayaan alternatif sebagai variabel leverage yang akan berpengaruh terhadap kemampuan variabel lain seperti perluasan sasaran penerima manfaat, penyesuaian beban kerja fasilitator dengan sistem penggajian yang layak, pelayanan perlindungan sosial yang lebih inklusif dengan dengan memasukkan kelas missing middle.

Pada posisi ini maka, perbandingan tahap 2 dan 4 terhadap tahap 7 perlu memasukkan pandangan baru dalam bentuk skema optimalisasi pembiayaan alternatif menggunakan welfare state yang secara feasible dapat diterapkan melalui pemanfaatan teknologi dengan cara mengumpulkan sumber daya di masyarakat yang tersebar berupa pendanaan bersama crowdfunding.

\section{Penerapan budaya yang layak sesuai dengan perubahan sistem yang diinginkan.}

Indonesia belum sepenuhnya menerapkan pandangan budaya welfare state pada perlindungan sosial. Berakar pada demokrasi pancasila, keadilan sosial bagi seluruh rakyat Indonesia dimaknai dalam perlindungan sosial terstruktur dan masif diberikan pada kelompok miskin. Kebijakan ini tentu bersumber pada keterbatasan kemampuan negara memberikan insentif. Fenomena ini tidak bisa lepas dari bagaimana negara mendapatkan sumber pendapatan berupa pajak nasional dan daerah. Alih-alih meningkatkan perlindungan sosial untuk kelas missing middle dan pemberdayaan sosial menuju masyarakat produktif, untuk menghilangkan kemiskinan saja masih menjadi permaslahan yang perlu diselesaikan apalagi dengan bertambahnya kelompok miskin baru karena dampak Covid 19. Pada posisi ini perlu adanya pandangan baru berupa pengelolaan kebijakan perlindungan sosial berbasis welfare state yang dapat diterapkan sesuai dengan perubahan sistem yang diinginkan.

Sebagai sebuah produk budaya, welfare state sudah dilaksanakan di German sejak tahun 1870 sebagai bagian dari pandangan Bismarck's conservative reforms. Pada era modern, TH Marshall mengidentifikasi welfare state mengkombinasikan demokrasi, kesejahteraan, dan kapitalisme yang sudah lama diterapkan sejak tahun 1930 an di Netherlands, France, Uruguay, New Zealand dan United Kingdom sebagai hak sipil dan politik.

Di Indonesia yang membuat pandangan welfare state berbeda adalah bagaimana cara pemerintah mengelola pajak sebagai sumber pendapatan negara. Dengan mendasarkan pada 
data rasio gini Maret 2020 sebesar 0,381 (BPS,2020) yang berarti kesenjangan pendapatan bertambah dengan adanya Covid 19 serta gambaran ketimpangan 1 persen orang di Indonesia menguasai 50 persen aset nasional (TNP2K,2019), maka jika dinaikkan jadi 10 persen keluarga mampu menguasai 70 persen (aset negara). Artinya sisanya 90 persen penduduk memperebutkan 30 persen sisanya. Dalam pandangan welfare state untuk mendekatkan kesenjangan, negara harus secara aktif dan masif memberlakukan pajak progresif terutama pada kelompok 10 persen keluarga kaya untuk didistribusikan kepada mereka yang masuk pada kelompok 90 persen dalam bentuk perlindungan sosial dan jaminan sosial.

Pada saat ini instrumen pajak berlaku sama bagi semua dalam bentuk Pajak Penghasilan (PPh), Pajak Pertambahan Nilai (PPN), Pajak Penjualan atas Barang Mewah (PPnBM), Pajak Bumi dan Bangunan (PBB), dan Pajak Daerah. Alasan keadilan sosial dan demokrasi pancasila membuat pemerintah tidak menerapkan pajak progresif karena akan berdampak pada dimensi sosial dan politik bagi 10 persen keluarga kaya yang dalam faktanya mereka mempunyai karyawan dari kelompok 90 persen yang berdampak luas terutama dampak keberlangsungan usaha seperti potensi PHK (Pemutusan Hubungan Kerja) dan pemutusan kontrak.

Contoh baik dapat dilihat penerapan Welfare State di Swedia, Denmark, dan Perancis. Untuk mengatasi kesenjangan pemerintah tidak harus bekerja sendiri termasuk dalam hal pendanaan yang dapat bekerja sama dengan pihak swasta (Paul Spicker, 2000). Kritikan terhadap pandangan Spicker, keterlibatan pendanaan swasta berpotensi mempunyai faktor kepentingan yang dikembalikan dalam bentuk keuntungan lain seperti iklan dan pemasaran produk. Maka dalam pandangan welfare state diperlukan sumber pendanaan alternatif lain yang murni bertujuan untuk melakukan perlindungan dan jaminan sosial sekaligus mengurangi kesenjangan dalam bentuk transformasi masyarakat miskin menuju masyarakat produktif.

Alternatif lain yang dapat dilakukan adalah memanfaatkan besarnya jumlah penduduk Indonesia melalui pendanaan bersama bersifat sukarela sebagai budaya baru mencerminkan konsep welfare state. Terdapat pergeseran pandangan dari pendanaan bersumber pada instrumen pajak yang memaksa coersive menjadi ajakan pemerintah yang bersifat sukarela persuasive. Budaya pendanaan bersama yang diterapkan dalam bentk crowdfunding yang penerapannya dapat diintegrasikan dengan big data yang menghubungkan data keluarga penerima manfaat, program pemberdayaan usaha, serta pemerataan serapan UMKM (Usaha Mikro Kecil dan Menengah) yang terhubung ke pasar. 


\section{Membangun model sistem dinamis dari penyelesaian permasalahan}

Berdasarkan langkah tahap 6 memasukkan budaya yang dapat dikembangkan untuk perbaikan sistem, maka di dapat permodelan sistem dinamis dengan variabel crowdfunding sebagai pembiayaan alternatif yag terintegrasi dengan big data e-PKH serta pengintegrasiaan terhadap Kredit Usaha Mikro, Kube PKH, Kebutuhan Pasar, Pelatihan/Sertifikasi, dan Sektor Informal. Sistem Crowdfunding berbentuk skema pendanaan yang ditawarkan kepada kelas menengah dan atas secara sukarela membantu kepada mereka yang membutuhkan.

Rich Picture berdasarkan budaya layak sesuai dengan sistem yang diinginkan

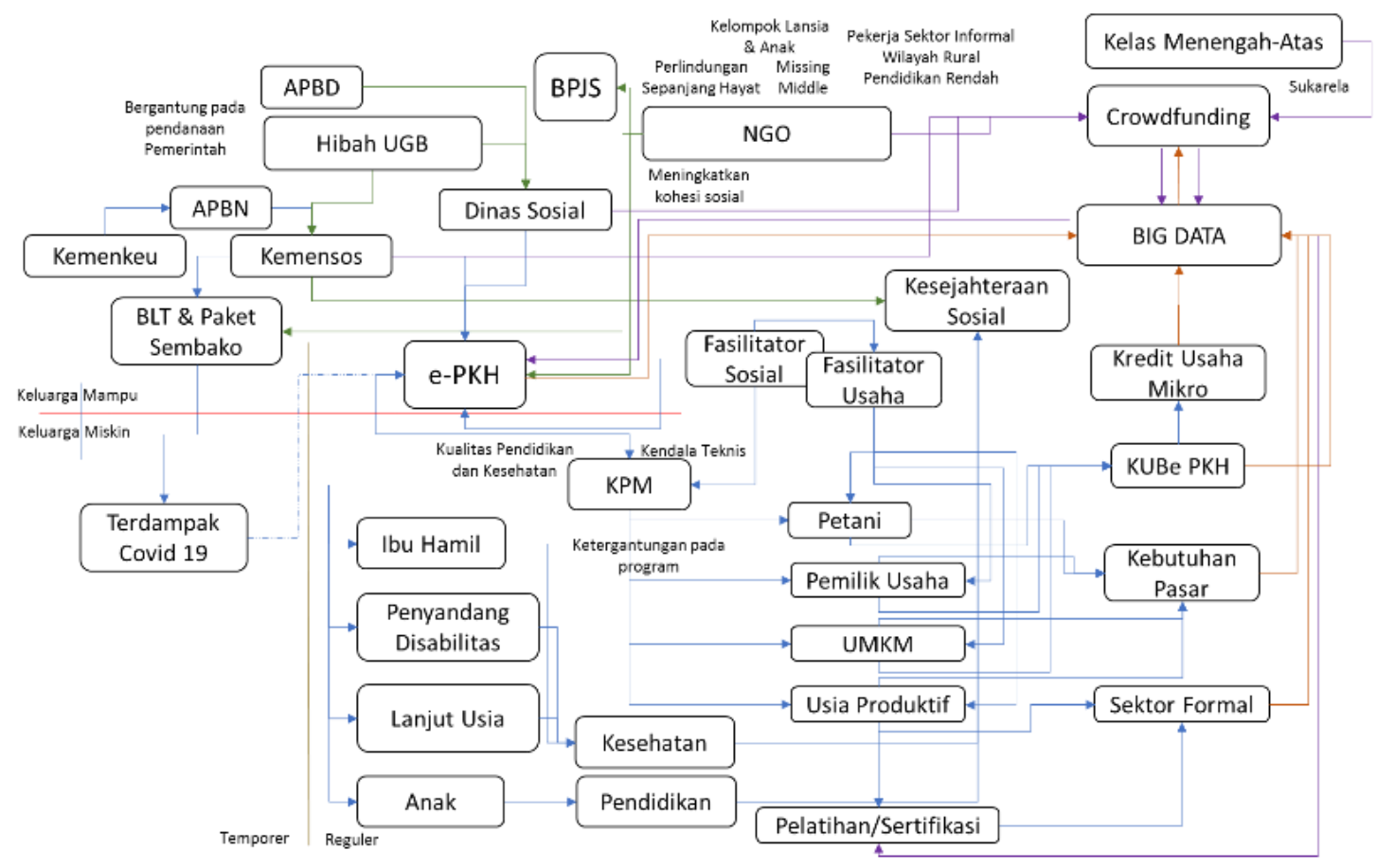

Gambar 4

Solving Situation

Sumber (Hasil Analisis Penulis)

Menu aplikasi berisi tentang data PKH beserta profil peserta dan kondisi ekonomi yang ingin ditingkatkan. Aplikasi juga diisi dengan skema pendanaan kredit usaha mikro yang ditawarkan kepada masyarakat luas dalam bentuk urunan kredit tanpa bunga yang disalurkan secara berkesinambungan untuk membiayai kelompok lain bagi yang sudah selesai melunasi 
kewajiban bayar. Untuk menjaga keberlangsungan program terus berjalan big data juga perlu diintegrasikan dengan kebutuhan pasar baik berupa barang dan jasa maupun kebutuhan pasar tenaga kerja yang dibuktikan dengan peningkatan pelatihan atau sertifikat.

\section{Pemecahan masalah berdasarkan RD pada langkah sebelumnya}

Berdasarkan langkah tahap 7 dapat diketahui root definition awal dengan berbagai permasalahan jaminan pengaman sosial perlu di integrasikan dengan program nyata pengentasan kemiskinan dan pemberdayaan seperti KUR dan KUBE serta memperhatikan kebutuhan pasar terhadap hasil produksi PKH dan kebutuhan pasar tenaga kerja terutama di sektor formal. Upaya pengintegrasian dapat dilakukan dengan pemanfaatan big data menggunakan konsep negara kesejahteraan dalam bentuk crowdfunding yang menjembatani antara kelas menengah - atas dan bawah dalam bentuk penyaluran dana bersama yang dikoordinasi oleh pemerintah yang dapat dilihat pada RD tahap 7

\section{KESIMPULAN}

Penerapan kelayakan kultural dan Perubahan sistem yang diinginkan dalam dunia nyata

Setelah penyesuaian telah dilakukan di antara tahap 8, 2 dan 7 serta di antara tahap 5, 6 dan 7, dapat disimpulkan perubahan yang layak secara budaya dan diinginkan secara sistemik siap untuk diimplementasikan di dunia nyata. Dalam konteks analisis pemodelan sosial: Studi Soft System Dynamic Methodology (SSDM) melengkapi System Thingking Causal Loop Diagram (CLD) terhadap Crowdfunding dalam pandangan negara kesejahteraan: Dampak revolusi industri 4.0 dan covid-19 terhadap program perlindungan sosial, beberapa masukan yang dapat di terapkan adalah:

- Pemberdayaan Masyarakat Miskin (+)

- Pengintegrasian KUBE dengan kebutuhan pasar (+)

- Pengintegrasian pelatihan penerima PKH dengan data kebutuhan sektor formal (+)

- Melepas ketergantungan APBN dan APBD (+)

- Melibatkan masyarakat kelas menengah dan atas dengan meningkatkan solidaritas sosial (+)

- Pengelolaan Big Data sebagai sumber analisis kebijakan sekaligus alat intervensi sosial (+)

\section{Learning Points}

Tahap selanjutnya adalah poin-poin pembelajaran yang didapat dari dunia nyata. Hasil analisis sensitivitas simulasi sistem komputer model problematis dan penyelesaian (Tahap 4 
dan 7 dalam SSDM) dapat membawa beberapa wawasan untuk belajar tentang perilaku 'patologis' dan 'sehat' dari sistem yang sedang dipelajari. Contohnya meskipun menganut negara demokratis, penggabungan konsep welfare state utuk meningkatkan kelompok masyarakat yang tidak mampu mengakses layanan dapat secara inklusif mengurangi kesenjangan perekonomian dan menangulangi kemiskinan.

Di sisi lain, proses implementasi Tahap 9, juga dapat membawa beberapa wawasan dari pengalaman menerapkan apa yang diusulkan pada tahap 6, untuk tujuan pembelajaran seperti dalam konsep sistem ternyata setiap bidang menjalin suatu rangkaian yang berkaitan secara sistemik. Perubahan layanan big data misalnya dapat berdampak pada semua bidang misalkan pengabungan data kelompok miskin dengan data kebutuhan industri dapat digunakan oleh pemerintah mendistribusikan secara merata potensi pemberdayaan sosial baik dalam bentuk produk sepertu hail usaha dari KUBE maupun dalam bentuk tenaga kerja yang diterima oleh pasar.

Setelah melalui sepuluh tahapan SSDM dalam konteks Crowdfunding dalam pandangan negara kesejahteraan: Dampak revolusi industri 4.0 dan covid-19 terhadap program perlindungan social, saran akademik yang dapat diberikan adalah perlunya kajian lanjutan mengenai kelayakan Crowdfunding sebagai cara baru pemerintah dalam menyikapi perlindungan perlindungan sosial. Tindak lanjut kebijakan pelepasan ketergantungan terhadap APBN dan APBN akan berdampak pada membaiknya perekonomian negara terutama menghadapi ancaman resesi akibat Covid 19. Implikasi kebijakan ini tentu tidak akan diterima dengan mudah oleh kelompok menengah atas sebagai pihak yang membantu, tetapi dengan akuntabilitas dan transparansi Big Data perlindungan sosial yang dapat di akses oleh semua pihak dapat dijadikan pintu masuk untuk mengajak mereka yang peduli terhadap sesama.

Melalui artikel, dapat pula dijadikan contoh penerapan metodologi SSDM dengan sumber data digital paper. Digital paper yang banyak dan beragam dapat dijadikan sebagai sumber informasi yang memberikan keberagaman situasi dan sudut pandang pada sebuah kondisi real word. Digital paper secara implisit juga memberikan informasi mengenai hubungan-hubungan yang ada dalam sebuah situasi sehingga dapat memberikan analisis pola perilaku dan kondisi dinamis. Sehingga mampu memberikan gambaran proyeksi dari keberadaan sebuah pemecahan masalah. 


\section{DAFTAR PUSTAKA}

\section{Kutipan Buku:}

Abbott, Andrew., (2014). Digital Paper: A Manual For Research and Writing With Library and Internet Materials. The University of Chicago Press.

Heimo, Lauri. (2014). The Idea of Conditional Cash Transfers. School of Social Sciences and Humanities. University of Tampere.

Spicker, Paul. (2000). The Welfare State: A General Theory. Sage Publication.

Tomlinson, Joe., (2019). Justice In The Digital State: Assessing The Next Revolution In Administrative Justice. Policy Press Shorts Policy \& Practice.

Wildemuth, Barbara M. (2017). Applications of Social Research Methods to Qusetion in Information and Library Science. Second Edition. Libraries Unlimited. California.

Williams, Bob and Richard Hummerlbrunner, (2009). System Concept in Action: A Practitioner's Toolkit. Stanford University Press

\section{Kutipan Artikel Jurnal:}

Adato, M. \& Hoddinott, J. (2007) Conditional Cash Transfer Programs: A Magic Bullet for Reducing Poverty? 2020 Focus Brief on the World's Poor and Hungry People. Washington: International Food Policy Research Institute.

Agriwal, Anjay, C. Catalini dan A. Goldfarb. 2014. Some Simple Economics of Crowdfunding. Innovation Policy and the Economy, Vo. 14 no.1 (Januari 2014): 63 - 97, https://www.jstor.org/stable/10.1086/674021

Ayurestianti. 2017. Evaluasi Pelayanan Kesehatan dan Pendidikan Program Keluarga Harapan (PKH). Jurnal Pemberdayaan Masyarakat: Media Pemikiran dan Dakwah Pembangunan vol.1, no. 2 hal 405-526

Bapenas. (2014). Perlidungan Sosial di Indonesia: Tantangan dan Arah ke Depan. Direktorat Perlindungan dan Kesejahteraan Masyarakat. Kemen PPN/Bappenas.

Beni, Sabinus \& Blasius Manggu. (2020). Efektivitas Program Keluarga Harapan Dalam Penanggulangan Kemiskinan di Perbatasan. Sosio Konsepsia Vol 9, No 2, Januari - April, Tahun 2020.

Cecere, Grazia, F. Le Guel dan F. Rochelandet. 2017. Crowdfunding and Social Influence: an Empirical Investigation. Applied Economics, vol.49 no.57 5802-5813, https://doi.org/10.1080/00036846.2017.1343450 
Gea, Fikar Damai S. (2016). Crowdfunding: Gerakan Baru Kegotongroyongan di Indonesia (Tinjauan Evolusi Gerakan Kolektif dalam Media Baru). Prosiding Konferensi Nasional Sosiologi V, Vol. II, Asosiasi Program Studi Sosiologi Indonesia, Padang 18 -19 Mei 2016.

Habibullah, (2017). Perlindungan Sosial Komprehensif di Indonesia. Sosio Informa Vol. 3, No. 01, Januari - April 2017.

Irfan, Maulana. (2016). Crowdfunding Sebagai Pemaknaan Energi Gotong Royong Terbarukan. Social Work Journal, Vol 6, no 1 2016, https://doi.org/10.24198/share.v6i1.13145

Kustanto, Munari. 2019. Konstruksi Soial Tentang Pendidikan Pada Keluarga Penerima Manfaat Program Keluarga Harapan di Kabupaten Sidoarjo. Sosio Konsepsia Vol. 8, No 03, Mei - Agustus, Tahun 2019.

Risqina, Eky. 2020. Dampak Program Keluarga Harapan (PKH) Terhadap Keluarga Miskin di Kabupaten Pekalongan (Studi Kasus di Kecamatan Wonopringgo). Tesis Program Pendidikan Ilmu Pengetahuan Sosial Universitas Negeri Semarang

Risqiana, Eky. (2019). Dampak Program Keluarga Harapan (PKH) terhadap Keluarga Miskin di Kabupaten Pekalongan (Studi Kasus di Kecamatan Wonopringgo). Universitas Negeri Semarang.

Rodriguez-Ulloa, R. \& Alberto Paucar-Caceres, (2005). Soft System Dynamics Methodology (SSDM): Combining Soft Systems Methodology (SSM) and System Dynamics (SD). Systemic Practice and Action Research volume 18, pages303-334(2005) https://doi.org/10.1007/s11213-005-4816-7

Sari, A. Gita dan Aufarul Marom. 2020. Evaluasi Program Keluarga Harapan dalam Rangka Mengatasi Permasalahan Pendidikan dan Kesehatan di Kecamatan Semarang Utara Kota Semarang. Jurnal of Public Policy and Management Review, Vol.9 no.1

Suleman, S. Adisanjaya dan R. Resnawaty. 2019. Program Keluarga Harapan (PKH): Antara Perlindungan Sosial dan Pengentasan Kemiskinan. Prosiding Penelitian dan Pengabdian kepada Masyarakat, Vol. 6 No.3

\section{Kutipan Website:}

BPS. (2020). Tingkat Ketimpangan Pengeluaran Penduduk Indonesia Maret 2020. Badan Pusat Statistik. 
https://www.bps.go.id/pressrelease/2020/07/15/1748/gini-ratio-maret-2020-tercatatsebesar-0-381.html

Fauzia, Mutia. (2020). Pemerintah Proyeksi Ekonomi RI Negatif 3,8 Persen Kuartal II 2020, https://money.kompas.com/read/2020/06/19/120300626/pemerintah-proyeksi-ekonomiri-negatif-3-8-persen-di-kuartal-ii-2020?page=1. diakses 19 Juni 2020.

Fauzia, Mutia. (2020). Semua Sektor Anjlok Akibat Corona, Realisasi Penerimaan Pajak Jeblok, https://money.kompas.com/read/2020/06/16/144308526/semua-sektor-anjlokakibat-corona-realisasi-penerimaan-pajak-jeblok?page $=2$.

Hanafi, Ristu., (2019). Agar Akurat, Kemensos Mulai Terapkan e-PKH. https://news.detik.com/berita-jawa-tengah/d-4655180/agar-akurat-kemensos-mulaiterapkan-e-pkh diakses 23 Juni 2020.

Huda, Kharisma., Diah Hidayati, \& SMERU. (2020). Strengthening Economic Opportunities For Program Keluarga Harapan Families. Kemensos, https://kemsos.go.id/buku-laporanstudi-program-keluarga-harapan-pkh diakses 19 Juni 2020.

Julita S, Lidya. \& Cantika Adinda Putri., (2020) Perangi Covid-19 Paksa Jokowi Tambah Pembiayaan APBN Rp 853 T. Kusuma, Hendra. (2020). Kengerian Corona: Cuma dalam 2 Bulan Terjadi Lonjakan Kemiskinan, https://finance.detik.com/berita-ekonomibisnis/d-5004662/kengerian-corona-cuma-dalam-2-bulan-terjadi-lonjakan-kemiskinan.

Manalu, Sonny W. (2019). Kemensos Luncurkan Aplikasi e-PKH, https://www.kemsos.go.id/kemensos-luncurkan-aplikasi-e-pkh, diakses 19 Juni 2020.

Nugraheny, Dian Erika., (2020). Data Penerima Bansos Bermasalah, Ini Penjelasan Kemensos.https://nasional.kompas.com/read/2020/04/28/15065431/data-penerimabansos-bermasalah-ini-penjelasan-kemensos?page=all_. diakses 23 Juni 2020.

PKH (2020). Apa Itu Program Keluarga Harapan. Kemensos, https://pkh.kemsos.go.id/?pg=tentangpkh-1, diakses 19 Juni 2020.

Republik Indonesia. (2018) Peraturan Menteri Keuangan Republik Indonesia 102/PMK02/2018 tentang Klasifikasi Anggaran. Jakarta: Kementerian Keuangan.

Republik Indonesia (2019) Peraturan Menteri Sosial Republik Indonesia Nomor 8 Tahun 2019 Tentang Pengelolaan Hasil Pengumpulan Sumbangan Masyarakat Dari Penyelenggaraan Undian Gratis Berhadiah Dalam Bentuk Uang. Jakarta: Kementerian Sosial.https://www.cnbcindonesia.com/news/20200406172449-4-150109/perangicovid-19-paksa-jokowi-tambah-pembiayaan-apbn-rp-853-t diakses 24 Juni 2020. 
Crowdfunding Dalam Pandangan.....

Nur Muhammaditya Priatmaja Husnanto, Bunga Pertiwi Tontowi Puteri, Rahmalia Rifandini

Sugianto, Danang., (2020). Mensos Akui Tak Verifikasi Data Penerima Bansos Tunai. https://finance.detik.com/berita-ekonomi-bisnis/d-5021096/mensos-akui-tak-verifikasidata-penerima-bansos-tunai diakses 23 Juni 2020.

TNP2K. (2019). Penyampaian Laporan Akhir TNP2PK 2014-2019. https://www.youtube.com/watch?reload=9\&v=jmDckDwCfZw diakses 17 Agustus 2020 .

TNP2K. (2018). The Future of The Social Protection System in Indonesia: First Edition. http://www.tnp2k.go.id/downloads/the-future-of-the-social-protection-system-inindonesia:-social-protection-for-all 